\title{
新时代高校思政教育与大学生职业生涯规划的融合与发展
}

\author{
井晓昌 \\ 上海第二工业大学 \\ DOI:10.32629/er.v2i12.2294
}

[摘 要] 目前,随着大学生就业形势日益严峻,对高校大学生职业生涯规划课程的改革创新提了更高要求,尤其是在新技术革命影响下剧烈的社 会变迁当中,思考如何培养时代大学生,解决好当今面临的就业难等问题。本文仔细分析了当前职业生涯规划课程的不足,结合当前新时代高校 思想政治教育的新方向, 论述促进高校思想政治教育与大学生职业生涯规划融合发展的新思路,进而探索在新时代能够适应国家社会发展需要 的人才培养路径。

[关键词] 新时代; 高校思政教育; 职业生涯规划

近年来, 大学生就业难问题日益突出, 每逢毕业季, 接连上演 “史上最 难就业季” 现象, 据教育部统计, 2019 年我国大学毕业生高达 840 多万人, 再创历史新高。另一方面, 不少企业出现 “用工荒”, 招聘不到合适的人才。 这是当前我国就业市场呈现出的结构性失衡图景。因此, 为了解决大学生 就业难问题, 国内高校在大学期间开设大学生职业生涯规划课程, 以及设 置各种类型的就业指导中心。但是, 从学生的反馈来看, 指导中心的形式化, 课程内容的形式化难以获得学生认可, 效果并不明显。大学生的素质和能 力与当前社会企业需求仍然存在脱节的现象。如何提高大学生职业生涯规 划课程的水平? 以及更深次追问, 如何培养新时代大学生帮助其更好适应 当今时代发展的需要, 树立正确的价值观、就业观等, 成为高校人才培养的 重要问题。

\section{1 新时代高校思想政治教育与职业生涯规划融合的新方向}

习近平总书记在 2019 年3月主持召开的思想政治理论课程教师座谈会 上, 强调 “思想政治理论课是落实立德树人根本任务的关键课程”, 这为新 时期高校思政教育工作指明了方向。习近平明确强调: “办好思想政治理 论课, 最根本的是要全面贯彻党的教育方针, 解决好培养什么人、怎样培养 人、为谁培养人这个根本问题。” 结合新时代发展的要求, 时代的新人应该 是德智体美劳全面发展、保持奋斗精神、以民族复兴为己任。这同时也为 高校的职业生涯规划课程改革创新指明了方向。新时代的思政教育与职业 生涯规划课程具有共同的目标, 关系密切, 各有其优势。思政教育更有利于 树立正确的价值观, 时代观, 职业生涯规划更有利于认识自我, 因此, 促进 新时代高校思想政治教育与职业生涯规划课程之间的融合发展, 为下一步 人才培养, 课程的改革创新指明了新方向。

\section{2 当前高校大学生职业生涯规划的困境与挑战}

职业生涯规划课程, 是高校解决学生就业难问题的重要举措。早在 2007年, 教育部就印发《大学生职业发展与就业指导课程教学要求》的文 件通知, 提倡全国所有普通高校将就业指导课程纳入教学计划之中, 并作 为公共通识课的教学内容之一, 贯穿学生从入学到毕业的整个培养过程。 但是, 在探索实践过程中, 对于来自西方职业生涯辅导的理念理解并不透 彻, 落实过程中, 国家一高校-教师, 对于如何做好职业生涯规划课程实际缺 少共识。与此同时, 近些年来, 信息革命的到来, 对年轻大学生群体影响也 更深刻。因此, 目前的大学生职业生涯规划课程存在困境与面临着新挑战。

2. 1 职业生涯规划课程的困境

2.1.1课程理念定位的功利化

目前高校的大学生职业生涯规划课程理念过于功利化, 各类的创业创 新教育, 倾向于用各类的性格测试、职业倾向测量等各类量表, 分析学生的 就业方向,进而提供一些面试技巧培训。强调性格倾向于职业类型的匹配
度, 以此作为职业生涯规划课程的重要内容。例如: 一些在大学生职业生 涯规划课程基础之上, 衍生出的一些课程创新举措, 大多是模拟面试大赛 形式, 盛行于各类校园活动中, 则是这种功利化趋向的体现。

2.1.2课程内容设计的教条化

由于对于职业生涯规划课程的教学并不清楚, 多数教师只能按照教科 书上的内容教条化教学。另一方面, 很多高校对于职业生涯规划课程的师 资力量的投入并不高, 很多都由其他教师或者辅导员来兼任, 缺少具有专 业的职业生涯辅导背景, 加上很多从教老师自身对于职业认识与如何就业 并不了解。因此, 按部就班, 照本宣科成为老师们的策略选择。

2.1.3课程体验效果的无趣化

课程理念的过于功利化, 加上内容的教条化, 使课程环节设计上并没 有太多创新, 由于很多学生久居象牙塔, 对于职业的认知以及如何就业, 还 处于迷茫阶段, 尤其是还处于刚刚入学不久的大学生中。课程的内容与自 我的迷茫点, 存在巨大鸿沟。因此, 学生对于课程的满意度并不高, 同时也 挫伤了教师的积极性, 进而课程效果并不理想, 较为无趣。

2.2 新技术革命影响下的新挑战

由于信息革命的到来，“互联网 + ”、大数据、 $5 \mathrm{G}$ 、云计算、人工智能 等新技术革命对社会的影响, 尤其是目前移动互联网的普及程度越来越 高。人类社会逐渐走向信息社会, 在此过程中, 我们与全球的接触越来越便 捷, 全球化的到来, 各类短时间辨别真假的爆炸信息扑面而来。例如, 大学 生群体中使用 “抖音”、“快手”、“直播”、“微博” 等各类新媒体的使用, 各种网红、达人、博主等流量明星在各类网络平台此起彼伏。各种为吸 引眼球只为博得流量宣称 “口号” 等亚文化价值观, 以及多元主义思潮 对当今社会中的个体, 尤其是正处于价值观形成过程中的大学生群体影 响深远。

在这样的背景下, 如何正确引导大学生的价值观树立和素质能力培养, 成为当前高校思想政治教育以及大学生职业生涯规划等课程共同面对的 新挑战。

\section{3 新思政教育与职业生涯规划课程融合发展的思路与路径}

新时代下思想政治教育与大学生职业生涯规划课程的融合发展为当 前的困境与挑战提供了新的思路。习近平讲到做好高校思政工作方法时强 调要 “三因三遵”, 即要因事而化、因时而进、因势而新。要遵循思想政 治工作规律, 遵循教书育人规律, 遵循学生成长规律, 不断提高工作能力和 水平。因此, 两者的融合可以从以下举措来思考:

3.1 坚持立德树人的理念, 树立思政与职规融合新理念

坚持立德树人, 是高校立身之本。这也是思想政治教育课程与职业生 涯规划课程共同的目标。首先, 要发挥好思政教育的价值观引领作用, 培养 
更好的择业观。这是大学生走向社会、走进职场, 作为新时代人才应当具 备的素质, 爱岗敬业, 能够在每个岗位上利用自己所长、所学, 贡献自身的 力量, 实现人生价值。例如, 外卖日益火热, 很多大学生主动投入到骑手当 中, 薪资水平也非常不错, 甚至高于一些写字楼里的白领群体, 由于具备互 联网知识的人才不断进入, 外卖也从传统的饮食行业衍生的劳力劳动, 逐 渐变成互联网平台, 成为具有高附加值的互联网新业态, 也为社会提供了 更加优质便捷的服务。其次, 思想政治教育的融合, 可以帮助大学生更好的 将职业选择与国家时代的发展需求相结合。习近平曾在2013年5月给北京 大学考古文博学院2009级本科团支部全体同学回信中提到“只有把人生理 想融入国家和民族的事业中, 才能最终成就一番事业。” 其内在意涵, 在新 时代, 职业选择与时代发展相结合才能成就一番事业, 体现人生价值, 同时 也能够为国家和民族发展贡献力量。

3.2 加强紧密协同的合作, 丰富思政与职规融合新内容

新时代, 思想政治教育课程与职业生涯规划课程的融合, 对两者目前 的教育内容都提出了新的要求。应当遵循教书育人、学生成长规律。首先, 从课程体系设计的对象上, 要分类设计, 从价值观培养、到自我认知、再到 技巧的培养, 循序渐进的对各年级学生群体设计相适应的教学内容, 例如, 大一学生群体, 应该强调职业认知与价值观的培养, 要将价值观的培养与 职业的认知相结合, 润物细无声; 大二群体, 要强调自我认知与职业能力相 结合, 认知到自身的优势与不足, 从而帮助学生, 因材施教, 有针对性培养 学生的能力与素质; 其次, 从课程内容的教学力量上, 要促进思政教师与职 业生涯规划课程教师之间深度的交流与互动, 共同设计和探讨, 丰富课程 内容, 进而能够逐步探索出一套真正深入学生心理的精品课程。

3. 3 树立 “互联网+”思维, 创新思政与职规融合新方式

信息革命的到来, “互联网+” 已经是当今时代的标注, 正在催生新行 业以及深度影响相关产业、社会生活等。我们更应当因势利导, 树立 “互 联网+”思维, 拥抱新技术, 创新思想政治教育与职业生涯规划课程融合的 新方式。利用互联网的优势服务于课程教育, 设计新型的教学方式。可以 依托互联网平台, 集聚各方的力量, 借助企业、高校、专业顾问等多方的合 作与协同, 共同参与设计培养; 同时, 还可以利用互联网工具, 例如大数据 等分析工具, 更好地帮助学生认知自我与职业分析; 于此同时, 也要借助互 联网平台将更多优质的课程资源, 在高校学生之间进行资源共享。在这个
过程中, 也可以将正确的价值观在互联网社会中传播开来, 促进社会的风 清正气。

\section{4 结论与讨论}

在新时代背景下, 我们正处于百年未有之大变局。在新一轮技术革命 影响下, 人们的日常社交与生活娱乐方式, 正在发生着深刻的变化。社会中 的产业、职业正在被重塑或者创造, 如何适应和满足新时代社会发展的需 要。尤其是当前中国正处于民族复兴的紧要关头, 在这样剧烈变化的时代, 如何能够培养新时代的接班人, 为国家与民族事业发展培养优秀人才。对 于我国高等教育的培养来说提出了更高的挑战。当前的大学生就业难和就 业市场的结构失衡问题, 为我们当前的思想政治教育与职业生涯规划课程 的改革创新提出了新课题。

我们应该在新时代背景下, 促进思想政治教育与职业生涯规划的融合 发展, 结合各自所长, 发挥思政教育的价值观引领, 坚持立德树人的理念, 加强相互之间的协同合作, 利用 “互联网+” 思维创新课程方式等, 更好促 进两者之间的融合, 进而培养出适应国家时代发展需要的社会主义优质人 才。十九届中央委员会第四次全体会议中已经明确强调 “完善立德树人体 制机制, 深化教育领域综合改革, 加强师德师风建设, 培养德智体美劳全面 发展的社会主义建设者和接班人。”做好新时代思想政治教育大学生职业 生涯规划教育融合发展, 也是高校教学领域深化改革的重要探索, 也是人 才培养的内在意涵。

\section{[参考文献]}

[1]尹大伟.大学生职业生涯规划与思政教育的结合与实现 [J]. 学理 论,2014,(32):278-279+286.

[2]戴树根,齐佳.论大学生职业生涯规划与思想政治教育的有效契合 [J].湖南科技大学学报(社会科学版),2009,12(04):1 18-121.

[3]康胜.论思想政治教育与大学生职业生涯规划的有机结合[J]. 西南 民族大学学报(人文社科版),2008,(10):275-278.

[4]张春香,王升臻.职业生涯规划:加强和改进大学生思想政治教育的 新载体[J].理论观察,2007,(02):128-129.

作者简介:

井晓昌(1991--), 男, 汉族, 河南洛阳人, 硕士研究生, 研究方向: 研究 方向网络思政研究、职业生涯规划。 